\title{
In vitro Anti-proliferative Characteristics of Flavonoids and Diazepam on MDA-MB-231 Breast Cancer Cells
}

\author{
Ji-Kwan Kim, Maan-Gee Lee, Jae-Tae Lee ${ }^{1}$ and Jeoung-Hee Ha* \\ Department of Pharmacology and 1Nuclear Medicine, School of Medicine, Kyungpook National University, Daegu 700-422, Republic of Korea
}

Received March 19, 2009 / Accepted June 10, 2009

\begin{abstract}
The beneficial use of sedatives is often required for medically ill patients. This study examined the effect of plant flavonoids and diazepam peripheral-type benzodiazepine receptor (PBR) activation and glucose utilization in breast cancer cells, along with their interactions. In estrogen receptor negative MDA-MB-231 cells, the anti-proliferative activity of fisetin $\left(3,7,3^{\prime}, 4^{\prime}\right.$-tetrahydroxyflavone) and diazepam was more prominent than in estrogen receptor positive MCF-7 cells. Unlike PBR ligands, treatment with $10^{-6} \mathrm{M}$ concentration of diazepam for 3 days exhibited anti-proliferative effects, while similar to apigenin (4',5,7-Trihydroxyflavone) and fisetin, diazepam hardly affected the PBR mRNA expression by MDA-MB-231 cells. Treatment with $10^{-6} \mathrm{M}$ concentration of flavonoids and diazepam for 3 days inhibited the glucose utilization of MDA-MB-231 cells. Treatment with $10^{-6} \mathrm{M}$ concentration of flavonoids and diazepam for 6 days showed increased cytotoxicity and reduced the PBR mRNA expression of the MDA-MB-231 cells. Apigenin enhanced diazepam-induced anti-proliferative effects on the MDA-MB-231 cells as well. All together, this study showed the in vitro anti-proliferative activity of flavonoids and diazepam on MDA-MB-231 breast cancer cells, plus additive enhancements. In conclusion, this study provides experimental basis for advanced trials in the future.
\end{abstract}

Key words : Flavonoids, diazepam, anti-proliferation, glucose utilization, breast cancer cells

\section{Introduction}

Patients with breast cancer experience a relatively higher incidence of sleep disorders and anxiety, especially in the case of advanced malignancy [2]. Activation of central-type benzodiazepine receptors (CBR) by clinically available sedatives elicit variety of pharmacological actions including anxiolysis and sedation. Diazepam, a prototype synthetic sedative, has been suggested to have anticancer effects $[3,14]$, yet diazepam is also known to bind peripheral-type benzodiazepine receptors (PBR). In particular, for highly aggressive MDA-MB-231 breast cancer cells, the activation of PBRs via binding to peri-nuclear/nuclear located receptors can induce the proliferation of cancer cells $[6,11,22]$. Furthermore, the prolonged use of synthetic benzodiazepines, like diazepam, is limited due to harmful adverse effects, including amnesia, muscle relaxation, and tolerance. Thus, to reduce such hazards, natural flavonoids isolated from folkloric plant tranquilizers are currently under investigation $[9,18,25]$. Unlike to diazepam, systemically administered natural bio-flavovoids like apigenin may be advantageous due to non-in-

\footnotetext{
*Corresponding author

Tel : +82-53-420-4834, Fax : +82-53-420-4834

E-mail : jhha4834@knu.ac.kr
}

volvement of PBR activation $[18,25]$. The routine use of 5 $\mathrm{mg}$ diazepam p.o. before the intravenous administration of fluoro-deoxy-glucose (FDG) has already been reported to render PET imaging ineffective [27]. It has also been reported that diazepam inhibits the function of glucose transporters (GLUT), insulin sensitivity, and hexokinase activity [21,23]. Thus, it can be postulated that sedatives may also have an in vivo anticancer efficacy. Accordingly, to obtain helpful information for the beneficial use of sedatives for patients with malignancies, this study examined the role of flavonoids and diazepam on PBR activation and glucose utilization in MDA-MB-231 breast cancer cells, along with the interaction.

\section{Materials and Methods}

\section{Materials}

The MCF-7/WT (wild type), MDA-MB-231, MCF7/DX (doxorubicin-resistant) human breast cancer cell lines were kindly provided by Dr. Sang-Hyun Kim (Kyungpook National University, School of Medicine), while the RPMI medium 1640, trypsin solution, sodium pyruvate, ethylene glycol-bis- (aminoethylether) N, N, N', N' -tetraacetic acid, fetal bovine serum (FBS), and antibiotics (penicillin and streptomycin) were all purchased from GIBCO (Grand 
Island, NY). The diazepam was kindly donated by Roche (Switzerland), and the other assay reagents and chemicals, including apigenin were all purchased from Sigma (St. Louis, MO, USA). The diazepam, Ro5-4864 (4'-chlorodiazepam), PK11195 (1-[2-chlorophenyl]-Nmethyl-N-[1ethylpropyl]-3-iso-quinolinecarboxamide), apigenin, and fisetin were prepared as stock solutions in $100 \%$ ethanol or methanol, then diluted with an aqueous medium to the final desired concentrations. The stock solutions of drugs were sterilized by filtration through $0.22 \mu \mathrm{m}$ disc filters (Gelman Sciences, Ann Arbor, MI) before being applied to the cells.

\section{Cell culture}

The cells were cultured at $37^{\circ} \mathrm{C}$ in a humidified incubator under 5\% CO2/95\% air in an RPMI 1640 medium supplemented with $10 \%$ FBS, $200 \mathrm{IU} / \mathrm{ml}$ penicillin, $200 \mu \mathrm{g} / \mathrm{ml}$ of streptomycin, and $1 \mathrm{mM}$ sodium pyruvate. The culture medium was replaced every 2-3 days.

\section{MTS assay}

The cytotoxicity was measured using a MTS assay (CellTiter $96^{\circledR}$ Aqueous One Solution Cell Proliferation Assay, Promega, USA). According to the protocols in the accompanying technical bulletin of the manufacturing company, 20,000 cells were plated per well in a 96- well plate. $100 \mu \mathrm{l}$ of a RPMI medium supplemented with $10 \%$ FBS was contained in each well of 96-well plates. After $24 \mathrm{hr}$, various concentrations of compounds were added. After $72 \mathrm{hr}$ incubation of drugs, $20 \mu \mathrm{l}$ of a MTS (3-[4,5-dimethylthiazol-2-yl]-5-[3-carboxymethoxyphenyl]-2-[4-sulfophenyl]2H-tetrazolium, inner salt) solution was added and the plates incubated for a further 1-4 hr. The optical density at $490 \mathrm{~nm}$ was measured using a 96-well plate reader. Since the quantity of formazan produced, as measured by the absorbance at $490 \mathrm{~nm}$, is directly proportional to the number of living cells in a culture, the reduction of absorbance when compared with the baseline absorbance of untreated cells represented the inhibition of cell survival (\%) in each group treated with a specific drug.

\section{Reverse-transcription polymerase chain reaction (RT-PCR)}

Total cellular RNA was extracted using TRIZOL (Invitrogen, USA). The RT was then performed using the total RNA incubated with an oligo dT primer, AMV reverse transcriptase, RNAse inhibitor, and RT buffer. The RT-PCR reactions were performed according to the protocols previously reported by Masser et al. [17]. The amplification process involved 38 cycles at $94^{\circ} \mathrm{C}$ for $45 \mathrm{sec}, 60^{\circ} \mathrm{C}$ for 45 sec, and $72^{\circ} \mathrm{C}$ for $2 \mathrm{~min}$. The primers for the cDNA amplification were supplied by Takara Korea Biomedical Inc. (Seoul Korea), where the forward and reverse primer sequences were: ACCAACTGGGAGGAGATGGAG and CGTGAGGA TCTTCATGAGGTAAGTC ( $\beta$-actin, 354 bp); CACGCTCTAC TCAGCCATGG and GCAGTAGTTGAGTGTGGTCGC (PBR, 298 bp).

\section{Glucose utilization}

The cells were cultured for $24 \mathrm{hr}$ in media containing the various drugs. The effects of the compounds on insulin-induced glucose utilization enhancement were also assayed in a medium containing either a vehicle or insulin $\left(10^{-6} \mathrm{M}\right)$ in the absence of FBS. Following the culture, the medium was pooled, while the cells were washed three times with phosphate-buffered saline (PBS) and assayed to count the live cells using an MTS assay kit. Meantime, the medium glucose was determined using an assay kit (GACO-20, Sigma, USA), then the consumption of the medium glucose by the cells was calculated based on the mg per live cell, and expressed as a percent modulation from a control.

\section{Statistical analysis}

The data represent the mean \pm standard error (SE). Intergroup comparisons of data were made using Student's t-test or ANOVA, followed by post hoc multiple comparision analysis with Turkey's test using the statistical analysis package (Systat, Intelligent Software, Evanston, IL, USA).

\section{Results and Discussion}

In a previous study by the current authors [14], the flavonoids and synthetic benzodiazepine diazepam showed a concentration-dependent inhibition of the cell survival of MDA-MB-231 breast cancer cells, where the $\mathrm{IC}_{50}(\mu \mathrm{M})$ for apigenin and diazepam was $0.6 \pm 0.1$ and $2.4 \pm 0.3$, respectively. Therefore, $10^{-6} \mathrm{M}$ apigenin, fisetin and diazepam was used in this study. As shown in Fig. 1, treatment with $10^{-6} \mathrm{M}$ apigenin, fisetin, or diazepam for 3 days inhibited the survival. Apigenin, fisetin, and diazepam inhibited the survival of the MDA-MB-231 cells by $4.6 \pm 1.9 \%$, $12.6 \pm 1.6 \%$, and $20.1 \pm 1.7 \%$, respectively, MCF-7/WT (wild 
(A)

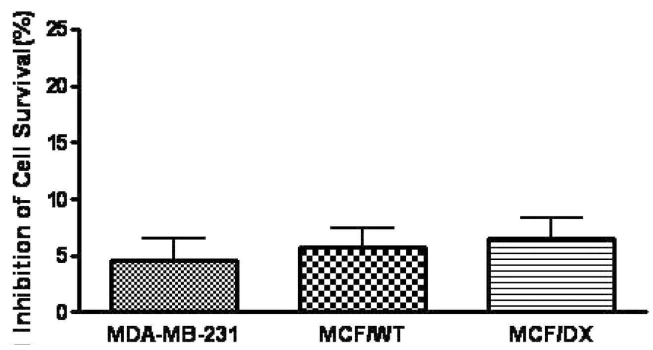

(B)

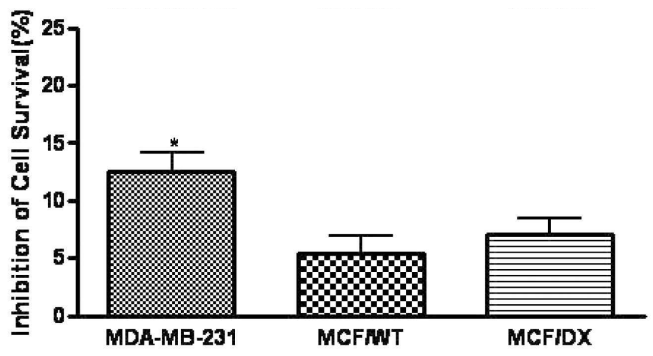

(C)

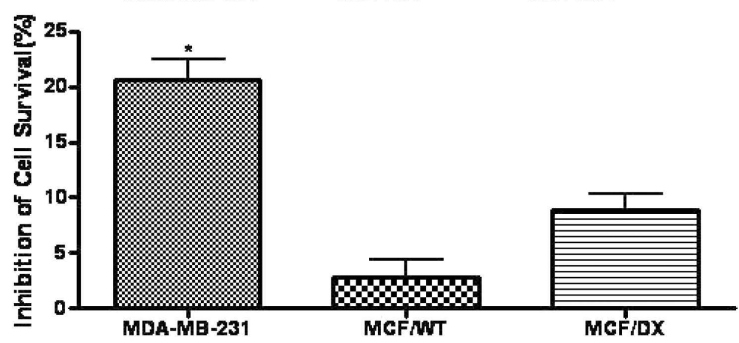

Fig. 1. Cytotoxic effect of apigenin, fisetin, and diazepam on various breast cancer cells. A: $10^{-6} \mathrm{M}$ apigenin $B: 10^{-6} \mathrm{M}$ Fisetin, C: $10^{-6} \mathrm{M}$ Diazepam. Drugs and vehicle (for control) were applied for 3 days. Data represent mean $\pm S E$ of eight experiments. ${ }^{*} \mathrm{p}<0.05$ : significantly different from others.

type) cells by $5.8 \pm 1.6 \%, 5.4 \pm 1.5 \%$, and $2.9 \pm 1.6 \%$, respectively, and MCF-7/DX5 (doxorubicin-resistant) cells by $6.5 \pm 1.9 \%$, $7.1 \pm 1.5 \%$, and $3.9 \pm 1.4 \%$, respectively.

In this study, the anti-proliferative activity by the fisetin and diazepam was more prominent in the MDA-MB-231 cells. MDA-MB-231 cells, which are estrogen-receptor-negative cancer cells, are known to have a higher proliferative potential than MCF-7 cells, which are estrogen-receptor-positive cancer cells. In the highly proliferative MDA-MB-231 cells, inhibitiory effect of cell survival could be manifestated as more prominent because of their rapid turnover of cell cycle.

In spite of the inhibitory effects of apigenin in all cell types, fisetin and diazepam in MCF and MCF/DX cells were very small (less than 10\%), shown in Fig. 1, these effects was significant $(p<0.05)$ versus control without sedatives. These suggest diazepam and flavonoids may overcome the action of efflux proteins in doxorubicin-resistant cells. Putative modulatory activity by flavonoids [16] on efflux protein has been already shown.
The activation of perinuclear/nuclear-located PBRs in highly aggressive MDA-MB-231 cells has previously been reported to elicit cancer cell progression $[6,11,22]$. In another report by the current authors [14], PK11195, a specific PBR ligand, had a proliferative effect on MDA-MB-231 cells, which was then reversed by statins, a HMG CoA reductase inhibitor. However, in this study, PK11195, a specific PBR ligand exhibited cancer cell proliferation. As shown in Fig. 3, although $10^{-6} \mathrm{M}$ diazepam inhibited the survival of the MDA-MB-231 cells by $20.7 \pm 1.7 \%$, PBR ligands consistently enhanced cell proliferation, where Ro5-4864 and PK11195 enhanced the survival of the MDA-MB-231 cells by $10.5 \pm$ $2.0 \%$ and $15.6 \pm 1.9 \%$, respectively, which was significantly $(\mathrm{p}<0.05)$ different from the baseline. As shown in Fig. 4 , in the presence of $10^{-6} \mathrm{M}$ PK11195, a specific PBR ligand, inhibition of cell survival (\%) by $10^{-6} \mathrm{M}$ apigenin-, $10^{-6} \mathrm{M}$ fisetin- and $10^{-6} \mathrm{M}$ diazepam was decreased by $1.4 \pm 0.1,-3.5 \pm 1.4$,

(A)

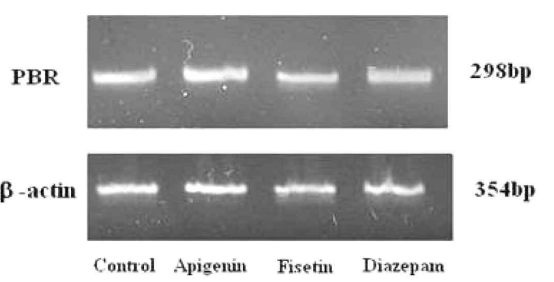

(B)

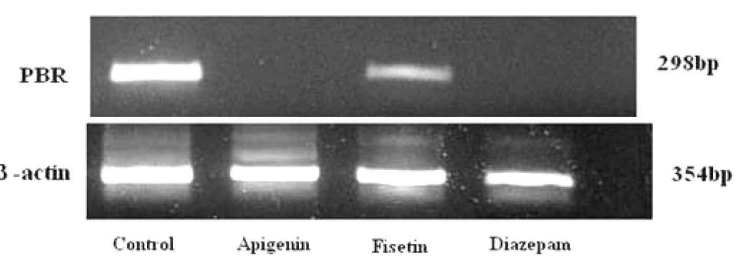

Fig. 2. Effect of apigenin, fisetin, and diazepam on expression of PBR mRNA in MDA-MB-231 breast cancer cells. $10^{-6} \mathrm{M}$ concentration of drugs and vehicle (for control) were applied for 3-(A) and 6 days (B).

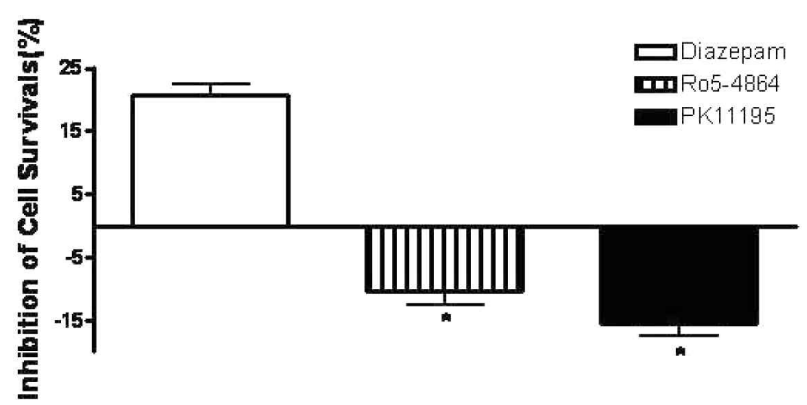

Fig. 3. Comparative effect of PBR ligands on survival of MDAMB-231 breast cancer cells. $10^{-6} \mathrm{M}$ concentration of drugs and vehicle (for control) were applied for 3 days. Data represent mean $\pm \mathrm{SE}$ of eight experiments. ${ }^{*} \mathrm{p}<0.05$ : significantly different from baseline. 


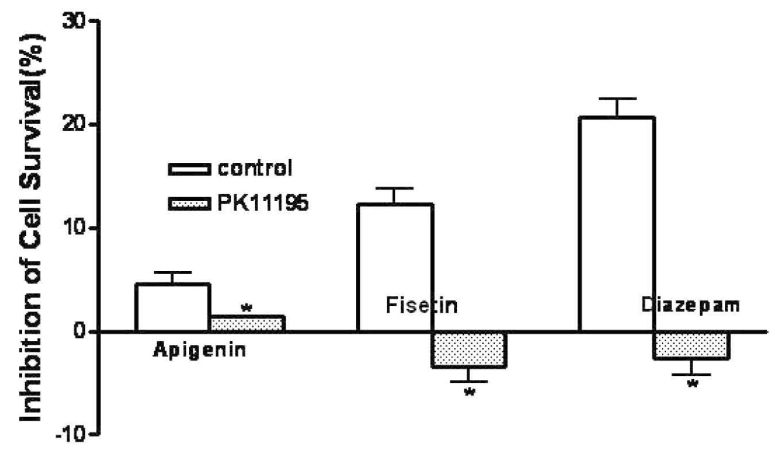

Fig. 4. Modulation of cell survival by PK11195, a specific PBR ligand in apigenin-, fisetin- and diazepam-induced cytotoxicity in MDA-MB-231 breast cancer cells. $10^{-6} \mathrm{M}$ concentration of drugs and vehicle (for control) were applied for 3 days. Data represent mean \pm SE of eight experiments. ${ }^{*} \mathrm{p}<0.05$ : significantly different from control.

and $-2.6 \pm 1.7$, which are significantly $(\mathrm{p}<0.05)$ different from those of control, $4.6 \pm 1.0,12.6 \pm 1.6$, and $20.7 \pm 1.7$, respectively.

Like to flavonoids, treatment for 3 days with diazepam elicited an anticancer cytotoxicity and hardly affected the PBR mRNA expression. As shown in Fig. 2 (A), treatment with $10^{-6} \mathrm{M}$ apigenin, fisetin, or diazepam for 3 days did not affect the PBR mRNA expression in the MDA-MB-231 cells. So, our results from 3 day treatment suggest the sedative induced anti-proliferative activity on independently from the PBR activation. In this study, for the MDA-MB-231 cells, cytotoxicity induced by flavonoids or diazepam was reduced by treatment with same concentration of PK11195, a specific PBR ligand. So, the effects of sedatives and PK11195 on viability of MDA-MB-231 cells seem to be independent. However, as shown in Fig. 2 (B), treatment with $10^{-6} \mathrm{M}$ flavonoids or diazepam for 6 days down-regulated the PBR mRNA expression in the MDA-MB-231 cells. Down-regulation of highly expressed PBR mRNA in MDA-MB-231 cells by cytostatic anticancer material, Ginkgo biloba extract (Egb 761) has already been reported [22]. In this study, for MDA-MB-231 cells, apigenin and diazepam treatment for 6 days decreased PBR mRNA expression. In a previous study by the current authors [14], inhibition of the survival of the MDA-MB-231 cells by treatment for 6 days with flavonoids and diazepam was several fold higher than that of cells treated for 3 days.

These results suggest that reduced activation of PBR due to down-regulation of PBR mRNA expression partially contributed the anticancer cytotoxicity of 6 day treatment groups. In several cancer cells, chemosensitizing effects of PK11195 on the anticancer activity induced by
(A)

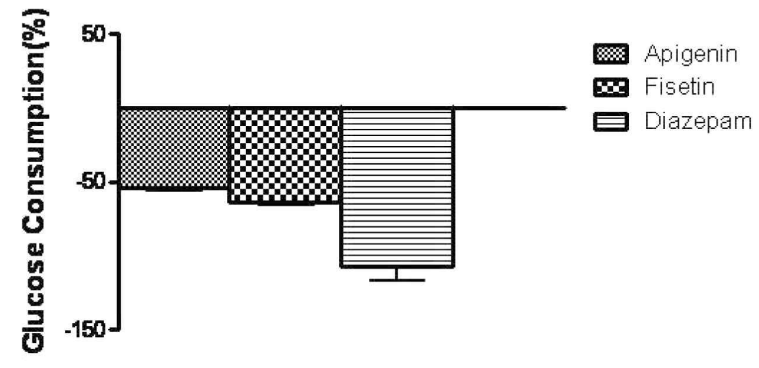

(B)

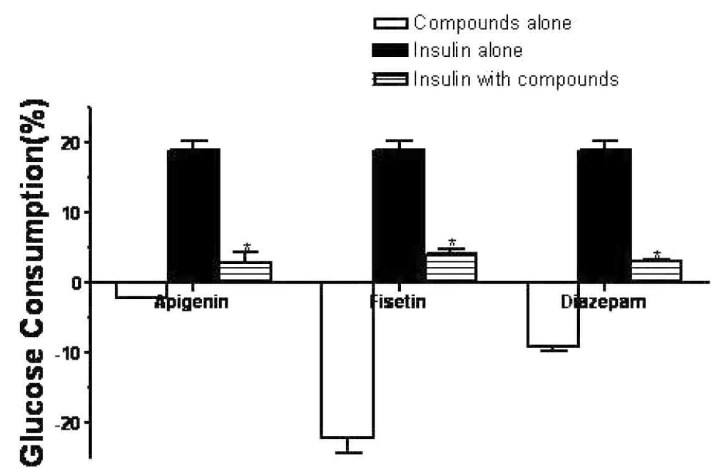

Fig. 5. Effect of apigenin, fisetin, and d'iazepam on glucose utilization by MDA-MB-231 breast cancer cells. A: assay performed in culture medium with FBS B: assay performed in culture medium without FBS. $10^{-6} \mathrm{M}$ concentration of drugs and vehicle (for control) were applied for 1 day. Data represent mean \pm SE of eight experiments. ${ }^{*} \mathrm{p}<0.05$ : significantly different from insulin alone.

chemotherapeutic agents has been reported as being independent from PBR activation [21-23]. As shown in Fig. 5 in another report by the current authors [14], for the MDA-MB-231 cells, flavonoids or diazepam augumented a chemosensitizing effects of PK11195 on the anticancer cytotoxicity induced by 5-fluorouracil, a known anticancer chemotherapeutic agent.

Cancer cells, characterized by high rates of proliferation, commonly overexpress glucose transporters to meet their increased requirement for energy. Breast cancer cells overexpress GLUT1 and often express the insulin-responsive glucose-transporter GLUT4, which exists primarily in muscle cells and adipocytes. In response to insulin, cytosolic GLUT4-containing vesicles translocate to the plasma membrane to facilitate glucose uptake. Cancer cells that express GLUT4 also exhibit an increased glucose uptake in response to insulin. In addition to enhancing the glucose uptake, insulin promotes proliferation, predominantly by signaling through the mitogen-activated protein kinase (MAPK) pathway. Insulin may also promote proliferation indirectly by increasing the amount of glucose available to cells $[1,26]$. Thus, agents that inhibit glucose uptake should decrease the 
proliferation of cancer cells. For example, naringenin has been shown to impede the cellular proliferation of MCF-7 breast cancer cells via glucose uptake inhibition [12]. In this study, the flavonoids apigenin and fisetin were found to inhibit the glucose utilization in MDA-MB-231 breast cancer cells, and also inhibited the insulin-induced enhancement of glucose utilization.

As shown in Fig. 5 (A), treatment with $10^{-6} \mathrm{M}$ apigenin, fisetin or diazepam inhibited the glucose consumption of the MDA-MB-231 cells incubated in culture media with FBS, which decreased by $54.5 \pm 1.2 \%, 63.7 \pm 2.3 \%$ and $107.2 \pm 9.6 \%$, respectively. As shown in Fig. 5 (B), treatment with $10^{-6} \mathrm{M}$ fisetin or diazepam inhibited the glucose consumption of the MDA-MB-231 cells incubated in culture media without FBS, which decreased by $22.0 \pm 2.3 \%$ and $9.0 \pm 0.6 \%$, respectively, and treatment with $10^{-6} \mathrm{M}$ apigenin slightly reduced the glucose consumption by $2.0 \pm 0.0 \%$. With the addition of $10^{-6} \mathrm{M}$ insulin in the cells incubated with medium without FBS, which has growth factors like insulin, the glucose consumption by the MDA-MB-231 cells increased by $19.0 \pm 1.2 \%$, however, in the presence of $10^{-6} \mathrm{M}$ apigenin, fisetin or diazepam, the glucose consumption with the same concentration of insulin decreased by $3.0 \pm 1.3 \%, 4.2 \pm 0.6 \%$ and $3.2 \pm 0.2 \%$, respectively, which was significantly $(p<0.05)$ smaller than that of cells with insulin alone, $19.0 \pm 1.2 \%$.

As one of action mechanisms for well-known anticancer effects of bioflavonoids including fatty acid synthase inhibition $[4,15]$, inhibitory of glucose utilization by apigenin and fisetin can be added. Furthermore, similar to flavonoids, diazepam also inhibited the glucose utilization of MDA-MB-231 cells, thereby providing a possible explanation for previous results reported by Zhuang et al. [27], where [18F] FDG PET imaging was disturbed by the administration of diazepam. Thus, when taken together, the evidence would seem to confirm the in vivo anticancer effect of a clinical dose of diazepam.

The use of synthetic benzodiazepines with a full agonistic spectrum carries certain risks for some patients, such as myo-relaxation, amnesia, and tolerance. Thus, various natural flavonoids, including chrysin (5,7-di-OH-flavone) isolated from Passiflora coerulea, apigenin (4',5,7-Trihydroxyflavone) from Matricaria recutita, and 6-methylapigenin from Valeriana Wallichii, have been shown to possess a selective and relatively mild affinity for BZD binding sites and a pharmacological profile compatible to partial agonistic action with in vivo parenteral administration. Further research has since

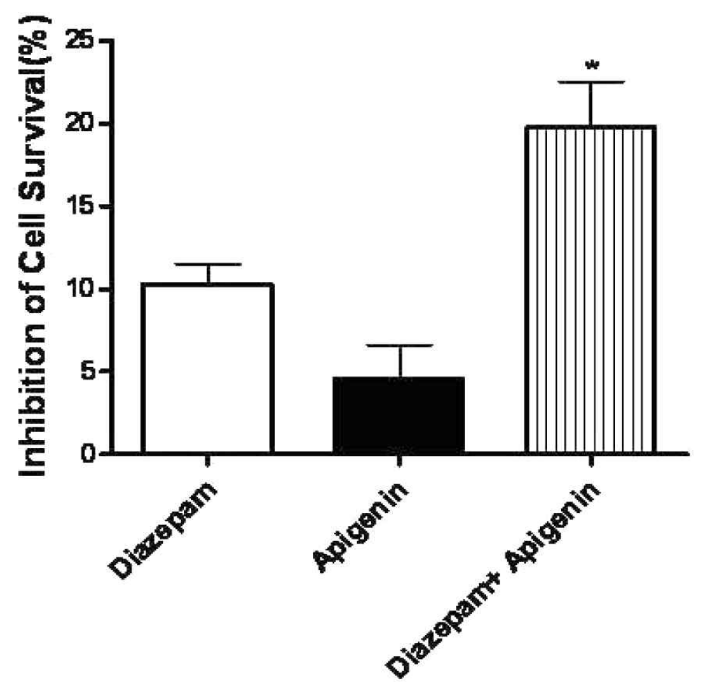

Fig. 6. Effect of apigenin on diazepam-induced cytotoxicity towards MDA-MB-231 breast cancer cells. $10^{-6} \mathrm{M}$ concentration of drugs and vehicle (for control) were applied for 3 days. Data represent mean \pm SE of eight experiments. ${ }^{*} \mathrm{p}<0.05$ : significantly different from control data and cells treated by diazepam or apigenin alone.

resulted in the production of synthetic flavonoid derivatives with improved biochemical and pharmacologic activities, and encouraged more extensive investigation of flavonoids $[18,25]$. Thus, based on the lack of any known toxicity and side effects, the associated use of natural sedatives with benzodiazepines in an optimal dose ratio has been suggested to potentiate human sedative therapy.

As shown in Fig. 6, for the MDA-MB-231 cells, apigenin did not reduce the anticancer cytotoxicity induced by the synthetic sedative like diazepam. As shown in Fig. 6, for the MDA-MB-231 cells treated with a combination of $10^{-6} \mathrm{M}$ diazepam and $10^{-6} \mathrm{M}$ apigenin, the percent inhibition of cell survival was $19.8 \pm 2.7 \%$, which was significantly $(p<0.05)$ higher than that for the cells treated with the same concentration of diazepam alone, and apigenin alone, at $10.3 \pm 1.2 \%$, and $4.6 \pm 2.0 \%$. However, the percent inhibition of cell survival, $19.8 \pm 2.7 \%$ in groups treated with a combination of $10^{-6}$ $\mathrm{M}$ diazepam and $10^{-6} \mathrm{M}$ apigenin was not significantly higher than the arithmetic summation of each value, the percent inhibition of cell survival by diazepam alone, $10.3 \pm 1.2 \%$ and apigenin alone, $4.6 \pm 2.0 \%$.

Repeated oral administration of specified mixtures of dried traditional sedative herbal remedies has been proved to improve chronic stress-induced anxiety in rats with few side effects [19]. The inclusion of dietary bioflavonoids is already known to lower the risk of cancer [13]. Cardenas 
et al. [5] reported on the antitumor activity of certain natural flavonoids and synthetic derivatives towards various human and murine cancer cell lines, and identified a potent anticancer cytotoxicity among them. All together, the present and previous $[10,14]$ studies by the current authors have shown the in vitro anti-proliferative activity of flavonoids and diazepam, plus this study also observed the additive enhancement. In conclusion, our data will provide experimental basis for advanced trials in the future, although the results given in this manuscript do not warrant the clinical efficacy of anxiolytic drugs (including natural flavonoids) for the treatment of cancer, Plus, the single or concominant use of anxiolytic flavonoids with diazepam would seem to be advantageous, due to the putative enhancement of anti-proliferative activity and reduction of the adverse effects. Especially in the medically-ill patients including oncologic patients, safer sedatives must be needed.

\section{References}

1. Binder, C., L. Binder, D. Marx, A. Schauer, and W. Hiddemann. 1997. Deregulated simultaneous expression of multiple glucose transporter isoforms in malignant cells and tissues. Anticancer Res. 17, 4299-4304.

2. Block, K. I., C. Gyllenhaal, and M. N. Mead. 2004. Safety and efficacy of herbal sedatives in cancer care. Integr. Cancer Ther. 32, 128-148.

3. Boitano, A., J. A. Ellman, G. D. Glick, and A. W. Jr. Opipari. 2003. The proapoptotic benzodiazepine Bz- 423 affects the growth and survival of malignant B cells. Cancer Res. 63, 6870-6876.

4. Brusselmans, K., R. Vrolik, G. Verhoeven, and J. V. Swinnen. 2005. Induction of cancer cell apoptosis by flavonoids is associated with their ability to inhibit fatty acid synthase activity. J. Biol. Chem 280, 5636-5645.

5. Cardenas, M., M. Marder, V. C. Blank, and L. P. Roguin. 2006. Antitumor activity of some naural flavonoids and synthetic derivatives on various human and murine cancer cell lines. Biol. Med Chem 14, 2966-2971.

6. Corsi, L., E. Geminaniani, R. Avallone, and M. Baraldi. 2005. Nuclear location-dependent role of peripheral benzodiazepine receptor (PBR) in hepatic tumoral cell lines proliferation. Life Sci. 76, 2523-2533.

7. Decaudin, D. 2004. Peripheral benzodiazepine receptor and its clinical targeting. Anticancer Drugs 15, 737-745.

8. Fennell, D. A., M. Corbo, A. Pallaska, and F. E. Cotter. 2001. Bcl-2 resistant mitochondrial toxicity mediated by the isoquinoline carboxamide PK11195 involves de novo generation of reactive oxygen species. Br. J. Cancer 84, 1397-1404.

9. Fernandez, S. P., C. Wasoski, L. M. Loscalzo, R. E. Granger, G. A. R. Johnston, A. C. Paladini, and M. Marder. 2006.
Central nervous system depressant action of flavonoid glycosides. Eur. J. Pharm 539, 168-176.

10. Ha, J. H., J. T. Lee, I. H. Cho, K. A. Chun, G. E. Park, H. C. Choi, K. Y. Lee, S. H. Kim, K. Suk, I. K. Kim, and M. G. Lee. 2007. Upregulation of PBR mRNA expression in human neuroblastoma cells by flavonoids. Phytomedicine 14, 232-235.

11. Hans, Z., R. S. Slack, W. Lia, and V. Papadopoulos. 2003. Expression of peripheral benzodiazepine receptor (PBR) in human tumors: relationship to breast, colorectal, and prostate tumor progression. J. Recept. Signal Transduct. Res. 23, 225-238.

12. Harmon, A. W. and Y. M. Pate. 2004. Naringenin inhibits glucose uptake in MCF-7 breast cancer cells: a mechanism for impaired cellular proliferation. Breast Cancer Res. 85, 103-110.

13. Kale, A., S. Gawande, and S. Kotwal. 2008. Cancer phytotherapeutics: role for flavonoids at the cellular level. Phytother. Res. 22, 567-577.

14. Kim, D. H., J. T. Lee, I. K. Lee, and J. H. Ha. 2008. Comparative anticancer effects of flavonoids and diazepam in cultured cancer cells. Biol. Pharm Bull. 31, 255-259.

15. Kuo, P. C., H. F. Liu, and J. L. Chao. 2004. Survivin and p53 modulate quercetin-induced cell growth inhibition and apoptosis in human lung carcinoma cells. J. Biol. Chem 279, 55875-55885.

16. Lima, S. A. C., J. Tavares, and P. Gameiro. 2008. Flurazepam inhibits the P-glycoprotein transport function: an insight to revert multidrug-resistance phenotype. Eur. J. Pharm 581, 30-36.

17. Maaser, K., M. Hopfner, A. Jansen, G. Weisunger, M. Gavish, A. P. Kozikowski, A. Weizman, P. Carayon, E. O. Riecken, M. Zeitz, and H. Scherubi. 2001. Specific ligands of the peripheral benzodiazepine receptor induce apoptosis and cell cycle arrest in human colorectal cancer cells. $\mathrm{Br}$. J. Cancer 85, 1771-1780.

18. Marder, M. and A. C. Paladini. 2002. GABA (A)-receptor ligands of flavonoid structure. Curr. Top. Med Chem 2, 853-867.

19. Mizoguchi, K., R. Ikeda, H. Shoji, Y. Tanaka, X.-L. Jin, Y. Kase, S. Takeda, W. Maruyama, and T. Tabira. 2009. Saiko-ka-ryudotsu-borei-to, a herbal medicine, prevents chronic stress-induced anxiety in rats: comparision with diazepam. Nat. Med (Tokyo) 63, 69-74.

20. Ognibene, E., P. Bovicelli, W. Adriani, L. Saso, and G. Laviola. 2008. Behavioral effects of 6-bromoflavanone and 5-methoxy-6, 8-dibromoflavanone as anxiolytic compounds. Prog. Neuro-psychoph 32, 128-134.

21. Oudard, S., L. Miccoli, B. Dutrillaux, and M. F. Poupon. 1998. Targeting the gene of glucose metabolism for the treatment of advanced gliomas. Bull. Cancer 85, 622-626.

22. Pretner, E., H. Amri, W. Li, R. Brown, C. S. Lin, E. Makariou, F. V. Defeudis, K. Drieu, and V. Papadopoulos. 2006. Cancer-related overexpression of the peripheral-type benzodiazepine receptor and cytostatic anticancer effects of Ginkgo biloba extract (Egb 761). Anticancer Res. 26, 9-22. 
23. Shaheen, A. A., M. A. Hamdy, A. A. Kheir-Eldin, Pel-Fattah, and A. A. Lindstrom. 1993. Effect of pretreatment with vitamin E or diazepam on brain metabolism of stressed rats. Biochem Pharmacol. 46, 194-197.

24. Walter, R. B., B. W. Raden, M. R. Cronk, I. D. Bernstein, F. R. Appelbaum, and D. E. Banker. 2004. The peripheral bezodiazepine receptor ligand PK11195 overcomes different resistance mechanisms to sensitize AML cells to gemtuzumab ozogamicin. Blood 103, 4276-4284.

25. Wasoski, C., M. Marder, H. Viola, J. H. Medina, and A.
C. Paladini. 2002. Isolation \& identification of 6-methylapigenin, a competitive ligand for the brain GABA(A) receptors, from Valeriana Wallichii. Planta Med 68, 934-936.

26. Younes, M., R. W. Brown, D. R. Mody, I. Fernandez, and R. Laucirica. 1995. GLUT1 expression in human breast carcinoma: correlation with known prognostic markers. Anticancer Res. 15, 2895-2898.

27. Zhuang, H., R. Hustinx, and A. Alavi. 2006. Effect of diazepam on the efficacy of dual-phase FDG PET imaging. Eur. J. Nucl. Med Mol. Imaging 33, 228-229.

초록 : Flavonoid류와 diazepam의 시험관 내 MDA-MB-231 유방암세포 증식 억제 효과

김지관 $\cdot$ 이만기 $\cdot$ 이재태 ${ }^{1} \cdot$ 하정희 $*$

(경북대학교 의학전문대학원 약리학교실, ${ }^{1}$ 경북대학교 의학전문대학원 핵의학교실)

Flavonoid류와 진정제의 시험관 내 암세포증식억제효과를 관찰하기 위하여, 암세포의 말초형 benzodiazepine 수용체(이하 PBR로 약함) 활성도와 포도당 활용도에 대한 효과를 유방암 세포를 대상으로 검색하였다. 동시에 이미 항암활성이 잘 알려진 flavonoid류와의 상호작용도 관찰하였다. Fisetin $\left(3,7,3^{\prime}, 4^{\prime}\right.$-tetrahydroxyflavone)과 diazepam의 암세포 증식 억제 효과는 악성도가 높은 MDA-MB-231 유방암 세포에서 MCF-7 유방암세포보다 저명하게 관찰되었다. MDA-MB-231 유방암세포에서, Apigenin (4',5,7-Trihydroxyflavone)과 fisetin 같은 flavonoid류처럼, $10^{-6} \mathrm{M}$ 농도의 dazepam을 3일간 처치하였을 때 암세포 증식 억제효과를 나타내었으며, 이는 PBR 배위자들의 암세포 증식 증진효과와는 차이를 나타낸 것이다. Flavonoid류처럼, MDA-MB-231 유방암세포에서, $10^{-6} \mathrm{M}$ dazepam의 3일간 처치는 암세포의 PBR mRNA 발현에 큰 영향을 미치지 않았다. $10^{-6} \mathrm{M}$ diazepam의 6 일간 처치는 암세포의 증식억제 효과가 증가되어 나타났으며, 암세포의 PBR mRNA 발현도 억제되었다. MDA-MB-231 유방암 세포에서, apigenin, fisetin과 diazepam은 포도당 유용도를 억제하였으며, 인슐린에 의한 포도당 유용도 증강효과도 억압하였다. Apigenin은 diazepam의 암세포 증식 억제 효과를 부가적으로 증강시켰다. 요약하면, 본 연구결과는 flavonoid류와 진정제의 시험관내 암세포 증식 억제효과와 부가적인 상호작용을 보여주고 있다. 결론적으로, 본 연구는 향후 좀더 진척된 시험을 위한 실험적인 기반 정보이다. 